\title{
Original Article \\ IMPORTANCE OF COURSE MODULE IN ACADEMIC PERFORMANCE OF STUDENTS AT UNIVERSITY \\ LEVEL: \\ (A Case of Year II Technology and science Faculty students- Jimma University) \\ (M Ranga Reddy*)
}

\begin{abstract}
In recent times, the rate of increase of students strength in the Universalities of Ethiopia is posing big problem to student Community in many ways due to lack of facilities to stay and study in the campus. However, University is centre for Academic Excellence and Training to all types of students to promote sustainable development in the country. But shortage of reference materials is a kind of problem to achieve desired goals set by the University. Here study is designed to get the information regarding role and importance of modules in Academic success of students community. Two cases are studied and discussed separately. In the case-I, year // Computer science students of Jimma University are taken as purposive sample and data is collected through the written examination. In case II, four groups of students are selected randomly from all PPC // students of Jimma University. Data is collected through
\end{abstract}

\footnotetext{
* Expatriate staff member, Education faculty, Mathematics Department, Jimma University
} 
Ethiop. J. Educ. \& Sc. Vol. 1 No.1 Sept. $2005 \quad 50$

the Interview Method. Chi-Square Test and other statistical Tests are used to analyze the collected data. Research findings show that course module is useful academically up to some level in improving the standards of students. I am recommending that steps should be taken to introduce course module at all levels of university studies.

\section{INTRODUCTION}

Generally education deals with the development of humankind in so many ways. In this process, education is being given to students with different methods namely Teaching, Demonstration, Laboratory Practice, Field Study and etc.. . The struggle to study is the main aim of the students in the Teaching Learning process. The aim of all above is to make Teaching - Learning process most effective. However, for this achievement, students need so many infrastructure facilities at university to acquire sufficient knowledge in their field. $(1,2)$. In the same time, University is a place for good training and to provide facilities to students like effective teaching, suitable atmosphere, sufficient library and laboratory . Generally Students rely on the lecture notes, reference and text books study materials at large to maintain good performance in their studies. $(2,3,4)$ With reference to all above we have 
Importance of Course Module in Academic Performance of Students M.Ranga Reddy (PhD)* 51 assumed that Text books and in academic success.: The Reference books are supposed to statement of the problem is, Under available plenty in number easily to new education policy of Ethiopia, the all students. Now-a - days, students number of students have been number in all Universities have been increased in the all Universities by increased by Ministry of education Ministry of education. In the same but in the same time basic facilities time, goal of the university is to are not being increased at the same maintain good standards in the rate. In this scenario, the rapid education given to the students. In growth of students number in each this scenario, The availability of text University, it is observed, certainly books and reference books at affects the availability of basic libraries is questionable! To meet facilities to all students staying in the the above problem and to reach the campus. $(4,5,6)$ In the same way, goal of university, course modules availability of text books and are supposed to be introduced at all reference books to all students at levels. This study is designed to find Libraries is the problem at this how course module helps to students juncture. The study is aimed to know for effective learning of complex about the role of course module with concepts in the compact academic reference to present Context and system. Here main investigation is relating to students' performance set around student's orientation 
Ethiop. J. Educ. \& Sc.

benefits and to make teaching learning process most effective. To

contrast the performance of students

in their studies with course module

and with out course module. To

know the difficulties of students in

getting text/reference books at all

libraries and how course module is

\section{METHODOLOGY :}

. The subjects of students are year

II students of Jimma University.

Case I and Case II are designed to collect data through written examination and Interview with students. Data is analyzed using various statistical Methods. Results are drawn on the Research findings.

Case I: The study is for year II computer students of Jimma University to know the significance
Vol. 1 No.1 Sept. 200552 helpful in their studies. Data is collected and analyzed through various Statistical Methods and Analysis, Discussion and Recommendations are made on the Research findings. This study is conducted from November 2004 and December 2004.

of course module in their academic success/performance. All students of computer science PPC-II students are taken as purposive sample. Two equally standard chapters namely Chapter I( Algebra and Logic) and Chapter II (combinatorics) of Math281 are taken and taught to all purposive sample students uniformly under same conditions. Course Module is prepared for Chapter II and distributed to all students. Written examination in Chapter I and 
Importance of Course Module in Academic Performance of Students $\quad$ M.Ranga Reddy $(\mathrm{PhD}) * 53$

Chapter II is conducted. The are present in the each group for

performance of all students is interview and each group is

evaluated and recorded. According questioned about the following two

to students performance, all students variables. Information through

are divided in to 4 categories discussion with students in each

namely Cat1 ( A grade students), group is recorded and analyzed

Cat $_{2}$ (B- grade students), $\mathrm{Cat}_{3}(\mathrm{C}-\quad$ using the various Statistical methods.

grade students) and Cat4(D-grade 1. Availability of Text/Reference

students). books at concerned libraries in

Jimma University.

Case // Interview with Year II

2. How course Module is useful for

students form the Technology and

regular studies.

the science Faculties of Jimma

Analysis and Result: Case I: The

University is the design. One group Summarized data is analyzed by the

from Computer Science PPC II Chi-square distribution with the

consists of 10 students are selected hypothesis there is no significance

randomly. Other 3 groups from the difference between two chapters

Technology and the Science one is with course module and other

faculties are selected randomly such one is with out course module in

that each group consists of 10 terms of students academic

students. Averagely, $60 \%$ students performance. 


\begin{tabular}{lrrrrr}
\hline & Cat $_{1}$ & \multicolumn{1}{c}{ Cat $_{2}$} & Cat $_{3}$ & Cat $_{4}$ & Total \\
\hline Chapter-I & 11 & 14 & 15 & 19 & 59 \\
\hline Chapter - II & 15 & 20 & 20 & 08 & 63 \\
\hline Total & 26 & 34 & 35 & 27 & 122 \\
\hline
\end{tabular}

\section{chapter * catagory Crosstabulation}

\begin{tabular}{|c|c|c|c|c|c|c|c|}
\hline & & \multicolumn{6}{|c|}{ catagory } \\
\hline & & & category 1 & category 2 & category 3 & category 4 & Total \\
\hline \multirow[t]{4}{*}{ chapter } & chapter 1 & Count & 11 & 14 & 15 & 19 & 59 \\
\hline & & $\begin{array}{l}\text { Expected } \\
\text { Count }\end{array}$ & 12.6 & 16.4 & 16.9 & 13.1 & 59.0 \\
\hline & chapter 2 & Count & 15 & 20 & 20 & 8 & 63 \\
\hline & & $\begin{array}{l}\text { Expected } \\
\text { Count }\end{array}$ & 13.4 & 17.6 & 18.1 & 13.9 & 63.0 \\
\hline \multirow[t]{2}{*}{ Total } & & Count & 26 & 34 & 35 & 27 & 122 \\
\hline & & $\begin{array}{l}\text { Expected } \\
\text { Count }\end{array}$ & 26.0 & 34.0 & 35.0 & 27.0 & 122.0 \\
\hline
\end{tabular}

\section{Che-Square Analysis:}

\begin{tabular}{lrrr}
\hline & & & \multicolumn{2}{c}{$\begin{array}{c}\text { Asymp. Sig. } \\
\text { (2-sided) }\end{array}$} \\
\hline Pearson Chi-Square & $6.746(a)$ & 3 & .080 \\
Likelihood Ratio & 6.882 & 3 & .076 \\
Linear-by-Linear & 3.871 & 1 & .049 \\
\hline
\end{tabular}


Importance of Course Module in Academic Performance of Students M.Ranga Reddy (PhD)* 55

Association

$\mathrm{N}$ of Valid Cases

122

a 0 cells $(.0 \%)$ have expected count less than 5 . The minimum expected count is 12.57

Students performance is observed with the chi-square analysis. The above test shows there is significance difference in the performance of students in

$90 \%$ level of confidence with 3 degrees of freedom. The hypothesis

is rejected. There is a significance

difference between the two

It is also observed from the Figure I,

the students performance in the

Chapter II (combinatrics supported

with course

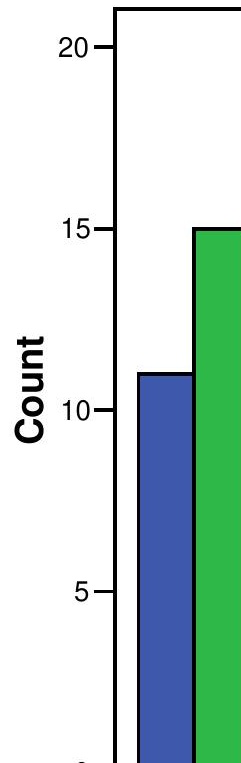

between two chapters, course

module is given for the chapter ii.

The Chi-Square analysis says, the

calculated value 6.746 is greater

than the table value 6.251 . at chapters. in terms of students

performance one is supported with

course module and other one is not

supported without course module.

opinion of students with Var1

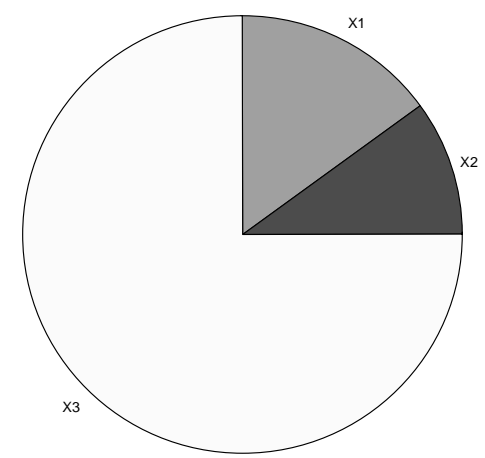

chapter

$\square$ chapter 1

$\square$ chapter 2 
I ( algebra and logic not supported

with course module). The bar graph justifies clearly the count range on the $y$-axis in the first three categories $A, B$ and $C$ are better in the Chapter II supported by course module while in the category $D$ is less comparing with chapter I.

module) rather good than in the

Case II: All collected qualitative information relating to above said two variables through the Group Interviews with year II students from Chapter the Technology and the science faculties of Jimma University is analyzed by the various statistical Figure // Opinion of students methods. Opinion of students is variable I observed and tabulated as follows. 
Importance of Course Module in Academic Performance of Students M.Ranga Reddy (PhD)* 57

: Var2 $=$ Role of course module in with variable

their studies $X_{1}=$ Positive opinion

in percentage $X_{2}=$ Normal

opinion in percentage $X_{3}=$

Negative opinion in percentage

$\mathrm{X}_{1} \quad \mathrm{X}_{2}$

$\operatorname{Var}_{1}$

15

75

10

$\operatorname{Var}_{2}$

80

15

05

Figure III Opinion of students

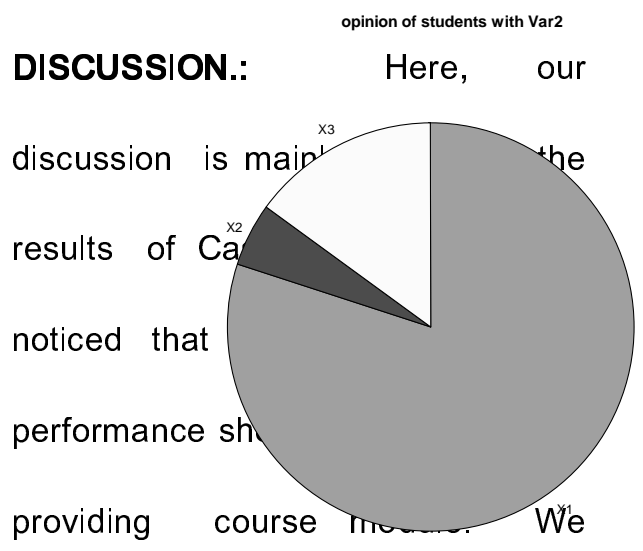

improve their academic performance

in so much

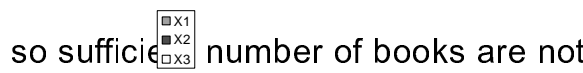
available at concerned libraries. From above analysis Results, we observed that course module plays can say that course module helps very important role in the busy to all types of students in the academic schedule because it saves universities up to some level in their time and covers all concepts. It is studies. Regarding with our very important to all students to reference (2), course module helps 
Ethiop. J. Educ. \& Sc.

Vol. 1 No.1 Sept. $2005 \quad 58$

to reach the goal of University and

improve the quality of education.

In the group interviews with students,

$75 \%$ students from all groups

expressed unhappy over availability

of text/reference books at their

concerned libraries It is observed

that from our reference (4), under the

new education policy number of

students were increased at large but

facilities are not being at the same

rate in the universities Campus.

It is noticed that $80 \%$ students from

group Interview say that course

module saves time and helps for

easy understanding of

all complex and covers all concepts.

Based on the students' opinion, we

say that course modules are the

alternative solution to provide effective education to all students

and at all levels in the present scenario under new education policy.

Regarding with reference to our

references $(1,2,4)$, to meet all above

students have been forced to

complete so many academic

requirements with in the

small time frame schedule. But

preparation of course module is not

simple task. It requires concerted

efforts of qualified professionals and

concerned authorities. It is

suggested that concerned authorities

has to encourage professionals by

incentives or academic promotion. It

is observed that all teachers in the

university are very busy with their

regular academic work, therefore,

University Teachers have to take

interest and have 
Importance of Course Module in Academic Performance of Students M.Ranga Reddy (PhD)* 59

taken for preparation

to spend their own time on the preparation of course module. In the same time concerned authorities have to provide basic facilities for smooth preparation. I am concluding that course modules are useful at all levels of university studies and improves students' academic performance.

\section{RECOMMENDATIONS:}

Researcher felt that course module helps students by and large in many ways at present conditions in the all Universities because of over crowded and insufficient facilities. So it is recommended that immediate steps should be and distribution of course

modules to all University students.

* It is recommended that concerned Professionals

have to be encouraged for preparation of course module and necessary facilities have to be provided.

\section{ACKNOWLEDGMENT:}

I am thankful to senior staff member of our department Ato Kassahun Melesse for his constant encouragement and suitable suggestions in the Research work of this paper.

I am also thankful to Ato. Mezgebu Nimeta, Instructor in the Statistics of our department for his support in the 
Ethiop. J. Educ. \& Sc.

Vol. 1 No.1 Sept. 2005

calculations of statistical results

using advanced methods.

\section{REFERENCES:}

1. Aim $s$ and objectives of

education: on

line Internet service: www.

Aimsedu.com.

2. Aims and objectives of

Universities:

On line Internet service: www.

Aimsuniv.com.

3. Read. J and Bergrde. Dec

2003:

Introduction to education.

Johan Willeay and Sons.

4. Documents, New education

policy by Ministry of

education, Addis Aababa.

5. Academic Rules and

Regulations:
Ethiopian universities,

Ethiopia6..

6. Tools of Teaching: Davis J

Year 2000

John Willison and sons Inc. 